University of Wollongong

Research Online

Faculty of Social Sciences - Papers (Archive) Faculty of Arts, Social Sciences \& Humanities

$1-1-2018$

Rural cultural resourcefulness: How community music enterprises sustain cultural vitality

Christopher R. Gibson

University of Wollongong, cgibson@uow.edu.au

Andrea Gordon

University of Wollongong, aeg999@uowmail.edu.au

Follow this and additional works at: https://ro.uow.edu.au/sspapers

Part of the Education Commons, and the Social and Behavioral Sciences Commons

Research Online is the open access institutional repository for the University of Wollongong. For further information contact the UOW Library: research-pubs@uow.edu.au 


\title{
Rural cultural resourcefulness: How community music enterprises sustain cultural vitality
}

\begin{abstract}
This paper explores how musical performance and expression catalyse rural cultural resourcefulness amidst uncertainty and change. We describe and then challenge conceptions of rural vulnerability and resilience amidst substantial social, environmental and economic change. Rural populations are increasingly constituted as vulnerable subjects within state-expert modelling of economic and environmental resilience. Yet, cultural resources and capacities are seldom acknowledged. Community music provides an often invisible and overlooked example. In rural locations music may struggle to be a commercially viable industry, but takes different forms in diverse community music enterprises, including non-profit clubs, orchestras, ensembles, choirs and festivals. Such enterprises sustain engaged music participation despite challenges of isolation and lack of critical mass, and enable people to adjust to change and develop social networks. In so doing, community music contributes to an evolving, prosaic sense of rural cultural resourcefulness. We document how rural Australian musicians negotiate isolation, distance, and new circumstances, and foster alternative spaces for creativity. Geographic and socioeconomic limitations triggered those with an insatiable desire to make and perform music to create their own opportunities through grassroots creativity. From this quotidian example we challenge state/expert conceptions of rural resilience. Resourceful creativities - focused on cultural vitality, process and everyday rewards rather than commercial successes - illustrate how rural people sustain cultural life amidst hardship, isolation and change.

\section{Disciplines}

Education | Social and Behavioral Sciences

\section{Publication Details}

Gibson, C. \& Gordon, A. (2018). Rural cultural resourcefulness: How community music enterprises sustain cultural vitality. Journal of Rural Studies, 63 259-270.
\end{abstract}


Gibson, C and Gordon, A (2018) Rural cultural resourcefulness: how community music enterprises sustain cultural vitality. Journal of Rural Studies 63, 259-270.

https://doi.org/10.1080/17406315.2018.1507788 


\title{
Rural cultural resourcefulness: how community music enterprises sustain cultural vitality
}

\begin{abstract}
This paper explores how musical performance and expression catalyse rural cultural resourcefulness amidst uncertainty and change. We describe and then challenge conceptions of rural vulnerability and resilience amidst substantial social, environmental and economic change. Rural populations are increasingly constituted as vulnerable subjects within state-expert modelling of economic and environmental resilience. Yet, cultural resources and capacities are seldom acknowledged. Community music provides an often invisible and overlooked example. In rural locations music may struggle to be a commercially viable industry, but takes different forms in diverse community music enterprises, including non-profit clubs, orchestras, ensembles, choirs and festivals. Such enterprises sustain engaged music participation despite challenges of isolation and lack of critical mass, and enable people to adjust to change and develop social networks. In so doing, community music contributes to an evolving, prosaic sense of rural cultural resourcefulness. We document how rural Australian musicians negotiate isolation, distance, and new circumstances, and foster alternative spaces for creativity. Geographic and socio-economic limitations triggered those with an insatiable desire to make and perform music to create their own opportunities through grassroots creativity. From this quotidian example we challenge state/expert conceptions of rural resilience. Resourceful creativities - focused on cultural vitality, process and everyday rewards rather than commercial successes illustrate how rural people sustain cultural life amidst hardship, isolation and change.
\end{abstract} Keywords: resourceful creativity, resilience, adaptiveness, isolation, creative frugality 


\section{Introduction}

All societies have traditions of musical performance and expression. Music is a powerful visceral force; it can foster feelings of community and belonging while establishing a sense of self-identity and place (DeNora 2000; Duffy 2000). In her seminal essay on the topic, Susan Smith wrote of the use of music by marginalised people throughout history as the one outlet available for them to 'enhance their lives and challenge their marginality' (Smith, 1997:516). This article discusses one such marginalised group: musicians within an isolated and sparsely populated rural Australian community. From this example we seek to contribute to a burgeoning conversation - in this journal and elsewhere (Anwar-McHenry 2009, 2011; Mayes 2010a; Edwards 2012; Luckman 2012; Waitt and Gibson 2013) - on the varied contributions of arts and cultural activities to rural life.

Further, we wish to respond to growing debate regarding conceptions of vulnerability and resilience as they pertain to rural populations. Rural people in Australia and elsewhere have dealt with enormous change, and face uncertain futures: harsh weather patterns fluctuating between droughts and floods, physical and mental isolation, ageing populations, and decreasing access to public services (Cocklin and Dibden 2004; Connell and Dufty-Jones 2014). A burgeoning literature is taking stock of capacities among rural communities to respond to socio-economic and environmental change, disasters and sudden shocks (Anderson 2014; Singh-Peterson and Lawrence 2014). In this article we focus on the rather more prosaic, and cultural, capacities among rural communities to adjust to change and challenging circumstances (cf. McManus et al, 2012; Roberts and Townsend 2015). In rural areas, especially where populations are sparse, musical participation - in festivals, orchestras, choirs - generates rare spaces for creative expression, knowledge sharing and various forms of emotional support (Anwar-McHenry 2011). Beyond dominant understandings of vulnerability and resilience - framed in social and economic terms by the state and policy/research experts as short term response to disaster (MacKinnon and Derickson 2013) - we document and theorise ongoing, everyday forms of rural cultural resourcefulness as catalysed through musical participation. We are less focused here on resilience as a response to disaster or sudden shocks, than to ongoing gradual change in a geographically marginal location, with accompanying 
persistent difficulties faced when commercial possibilities are limited. We highlight the contributions such cultural participation makes to the wider resourcefulness of rural communities (cf Anwar-McHenry 2011; Derrett 2009). Resourceful creativities, we argue, warrant closer attention within the wider debate about rural resilience, analysing the manner in which meaningful and active cultural life is sustained in rural areas.

Our paper is structured as follows: first, we overview the debate on conceptions of rural vulnerability and resilience, clarifying our distinctive response. Then, after a brief explanation of what is community music, along with a description of our case study location and methodology, we detail the story of musical practices in the Bega Valley, Australia. In a region where commercial music opportunities are fragile, community music programs flourish. Through listening to those involved in such programs, we explore the significance and meanings of music participation, and its wider social and creative role in ostensibly vulnerable rural places.

\section{Rethinking rural resilience: towards resourceful creativities}

Creativity is increasingly viewed as a facilitator of regional development via discrete cultural activities such as music, film, literature, fashion, and visual arts, where value is created not in physical production, but in in creative content, and its semiotic meaning (Scott 2000). Arts and cultural activities are in themselves nothing new; but in the past two decades, re-positioned as part of the creative industries, they have assumed an increasingly important position within regional development policy debates (Gibson and Klocker 2005; Scott 2006). The promise is that high value activities in the arts, culture and creativity can stimulate meaningful employment, attract tourists and inward investment, and also generate a lively cultural milieu that attracts innovative and highly educated people (Bell and Jayne 2010).

Subsequent work has sought to demonstrate how the arts and creativity contribute to regional development in more diverse and holistic ways (Waitt and Gibson 2013; Roberts and Townsend 2015). Beyond creative activities as rural economic revitalisation strategies (which quantitative modelling suggests are unlikely to yield 
significant increases in formal employment - see Argent et al 2013), are a host of contributions to the vitality of everyday life and resourcefulness of rural communities. The cultural activities that underlie commercial creative industries frequently survive - and even thrive - despite sparse and small populations, low incomes and the failure of commercial actors to maintain viable enterprises (Ward and O'Regan 2015). The absence of realistic commercial opportunities fuels 'creative frugality' (Gibson and Connell 2012:6) - the ability to pool scarce resources to sustain cultural activities, and thus generate vibrancy of another kind.

In theorising the social and symbolic significance of vernacular creative endeavours in rural contexts, we draw upon the antecedent work of Robyn Mayes (2010a, b), who examined the making of postcards in a small rural Australian town. In Western Australia metropolitan producers refused to print postcards of the town because they did not feel there was a sufficient market. A group of residents decided to design postcards themselves, more for the symbolic contribution to the town's identity and community than for any explicit profit. Creative practice can be a means for fulfilling needs that the commercial market cannot meet. In addition, creativity was used as a medium in which residents could catalyse sense of place, socialise and foster a sense of community (Mayes, 2010b). This too resonates with our example below, which focuses on musical practices as ongoing, everyday participation activities, rather than as exceptional or special events.

In community music, the emphasis is much less on the capacity to generate private sector incomes or singular 'successes' (as measured by commercial markets royalties, record sales, ticket receipts, rave reviews in commercial print media), and instead on the multiple everyday pleasures that stem from participation in a creative and expressive activity. Music practices are a means for the flourishing of new rural subjects in the community economy domain (cf. Gibson 2001), where social and cultural life generates a distinctive moral economy (Hesmondhalgh 2013) surrounding creative interactions.

From this distinctive cultural and creative practice, we seek to make a contribution to a burgeoning academic and policy debate examining rural vulnerability and resilience amidst widespread social, economic and environmental transformations (McManus et al 2012; Imperiale and Vanclay 2016). Such concepts as vulnerability, resilience and 
adaptiveness have assumed increased importance across rural studies, and social and ecological literatures amidst climate and economic crisis. Resilience is 'rapidly emerging as an idea 'whose time has come' in policy debates' (Martin and Sunley 2015:1) surrounding the capacities of urban, regional and local communities to respond to and cope with change.

A host of such changes have transpired in rural areas (Tonts et al 2012). These include: social and economic stresses from restructuring (Pritchard \& McManus, 2000; Lockie and Bourke 2001); changing geographies of investment and work in agriculture, forestry and mining (Tonts et al 2014); and heightened exposure to extreme climatic events as a consequence of global warming (Head et al 2011). Population decline and ageing in many rural areas have accompanied structural changes in agriculture (Cocklin and Dibden 2005), but are also amplified and counteracted in uneven ways by new urban-to-rural mobilities of retirees, lifestyle migrants and tourists (Connell and McManus 2011; Davies 2014). Increasing debts and costs of capital inputs, uncertainty over succession, and unpredictable growing seasons (including worsening floods and droughts) has seen many farmers leaving their fields (Lockie and Bourke, 2001; Wheeler et al 2012), or contemplating the future amidst growing concern over drought and climatic variability (Head et al 2011). Renewed questions are being asked about the vulnerability and long-term viability of rural communities (Martin and Budge 2011; Hogan and Young 2012).

In response there is a growing body of research documenting distinctly rural patterns of social, economic and environmental vulnerability and resilience (Beer et al 2012; Tonts et al 2014). Such research frequently undertakes sophisticated modelling of social and economic variables, that may include population ageing, growth and decline, industrial and employment mix, labour market and skills, remoteness, and existing agricultural and other land uses, overlaid with predictive models of biophysical and climatic change. Onset of more frequent extreme climatic events is frequently the core concern (Singh-Peterson and Lawrence 2014), spurred by growing need to model exposure and responses to disasters (Imperiale and Vanclay 2016). Less well understood are on-going, everyday experiences of vulnerability, and prosaic cultural practices that enhance longer-term social, economic and environmental resilience (Anderson 2008, 2014; Head et al 2011). 
Critically, resilience has tended to be defined by state agencies and expert knowledge (MacKinnon and Derickson 2013), rather than as an extension of capacities fostered within communities (Onyx and Leonard 2010). There is 'still considerable ambiguity about what, precisely, is meant by [resilience]' (Martin and Sunley 2015:1). The result is confused and imprecise use, informed by 'conceptual constructs, scientific traditions, and lack of interaction between the... academic communities involved' (Miller et al 2010:11). Bristow and Healy (2015:241) call for increased attention to the precise 'adaptive capacities of regional actors' and 'specifically what shapes how agents adapt, respond and react to crises'.

Meanwhile, critics have questioned a growing 'command and control' approach typically adopted by disaster management agencies, which 'results in an increasing dependency on external support and annihilates the potentialities of local communities' (Imperiale and Vanclay 2016:204). In contrast, ethnographic studies of rural populations adjusting to change have revealed on-going capacities to cope with crisis and upheaval linked to everyday vernacular and tacit knowledges, social cohesion, sense of place, local reliance, memories, and cultural inheritances (Head et al. 2011; McManus et al 2012; Pritchard et al 2012; Eriksen 2013; Anderson 2014; Gibson and Connell 2015). Rural populations that quantitative modeling portrays as vulnerable are being portrayed in ethnographic research as possessing considerable cultural resources, especially when viewed over the longer term. These stem from tight social bonds, and prior experiences of rallying together in response to economic recession and extreme weather and disaster events (Anderson 2008; Head et al 2011).

Amidst such divergent meanings and debates, MacKinnon and Derickson (2013:253) offer the concept of resourcefulness 'as an alternative approach for community groups to foster' in response to the state-expert domination of resilience policy debates. We accordingly adopt the concept here and, in light of Bristow and Healy's (2015) above call for precision of analysis, propose to extend the concept, as rural cultural resourcefulness. Here, rural cultural resourcefulness describes the manner in which cultural norms, meanings and practice inform creative and inventive everyday responses to change among groups of rural actors. Endurance, for instance, is a key rural cultural norm, informing cultures of farming and response to drought and climate crisis (Anderson 2014). It also, we argue, underpins the survival and vitality 
of cultural activities in otherwise difficult circumstances. Meanwhile, everyday cultural participation deepens social bonds and helps newcomers adjust (Verdich 2010). Managing community cultural groups and enterprises within constrained and challenging circumstances also fuels 'creative frugality' (Gibson and Connell 2012:6) whereby arts and cultural practitioners marshal resources and exercise growing skill and creativity in sustaining active cultural participation despite dwindling or nonexistent financial reserves. And, beyond benefits of social capital and resourceful creativity, cultural participation unleashes powerful symbolic meanings that sustain identities, belonging and self-confidence (Waitt and Gibson 2013). Arguably, no better is this exemplified than in the case of music: enabling rural voices to sing, and to be heard.

\section{Community music}

The case examined below is of community music in rural Australia. A brief discussion is thus warranted of what characterises community music, a term generally used to describe collective music practices distinct from, or opposed to, commercial music industries. Community music is a term used in ethnomusicology and studies of the sociology of music to describe non-industrial, non-capitalist forms of active musical participation (singing, playing instruments, performing in situ) that, in their original form, are not produced for the means of intellectual property generation, commercial distribution and consumption (Joseph 2007). Rather, community music is driven by desires to perform music for its own sake, and to educate, socialise and engage a community. Advocates for community music see it as an extension of the grounded performance practices that typified the pre-recording era: unpaid and embodied musical participation, within the social and cultural contexts of communities (Langston and Barrett 2008).

Exactly what constitutes 'community' has of course shifted and become more contested as digital technologies and urban living have spawned new social formations, and as extended families have shrunk, dispersed, and become more diverse (Walmsley 2000). In rural areas especially 'community' has long been a contested term (Cloke et al 1998). Uptake of new technologies such as computer music production and digital file-sharing, that has revolutionised the commercial music industry (Hracs 2012; Leyshon 2014), has to a degree penetrated the 
community music scene as well. Uploaded YouTube clips of social events and community music performances are ubiquitous. Nevertheless the zeitgeist in community music remains firmly centred on unpaid musical participation fuelled by, and celebrated within, a social context (cf. Finnegan 1989).

To some degree community music coincides with notions of 'amateur' performance practices - although the two phrases are not neatly synonymic. Many community music events, organisations and performances are sophisticated and well organised they simply exist outside the paid circuit that typically defines 'professional' musicians (cf. Luckman et al 2008). Paid professional music scenes tend to be driven by individual artists in search of waged pay, recording contracts and songwriting and broadcast royalties, and event promoters, licensing, publishing and recording companies in search of profit (Leyshon 2014). Typically, community music activities operate via organised non-profit clubs, societies and committees who bring together likeminded individuals because of a shared passion for a particular genre of music, a political orientation (as within many folk music clubs - see Begg 2011), or a commitment to promote music education and learning.

There are, however, inevitably times when aspects of community and commercial music intersect, and the boundaries between the two become blurred. Community musicians frequently purchase sheet music (in hard copy or online) and sometimes pay a commercial fee to license the rights to perform in public. Do-it-yourself recordings are often made, and sold informally as CDs, for money, even if there are no record labels or contracts involved. Community music nevertheless purports to exist largely beyond the commercial sphere, as a means of music education outside of schools and private lessons (Veblen 2008), or as something more political- 'music making with social goals' (Rimmer 2009:71). Community music provides opportunities for 'otherwise silent/ songless groups' (Breen 1994:322). Examples of this abound in rural areas, where opportunities to support commercial music industry growth are severely limited. 


\section{Case study context and method}

Fieldwork for this study was undertaken in the Bega Valley, a rural area on the far south coast of NSW, Australia (Figure 1), roughly equidistant from Sydney and Melbourne, and approximately 230 kilometres from the next nearest sizeable city, Canberra (which is separated from the south coast region by the Great Dividing Range). The Bega Valley has both coastal and inland towns - all modest. The largest are Bega (population 4,500 located 20 kilometres inland), and Merimbula (population 3,800 , located on the coast), and there is also a patchwork of smaller towns, villages and hamlets scattered across over 6,000 square kilometres of agricultural, forested and conservation land. All of the region's population centres are small; none could be called a city, and even the largest settlements barely constitute 'towns' as many residents of larger places might recognise them. Roads leading to Sydney, Melbourne and Canberra are all single-lane, windy, dangerous and slow. There is little public transportation and no linking rail line. Residents who do not have access to a personal vehicle are greatly limited in their mobility, and accessibility to community organizations and other services.

<Figure 1 about here - location map, Bega Valley>

Rural Australia faces many challenges, with senses-of-self and ideas of personal and community identity in flux. The Bega Valley epitomises these transitions and tensions. Traditional timber and whaling industries have contracted or disappeared entirely amidst restructuring and heightened environmental concern. Despite its iconic 'Bega Cheese' cooperative and factory, dairy industry restructuring and mechanisation has meant dwindling jobs. Downward price pressures on dairy farmers (bound up in corporate processor and supermarket power relations - see Pritchard 1996), has encouraged consolidation, farm exit and lack of succession.

Unemployment remains above state and national averages. Counteracting population mobilities are also reshaping the region's demographic profile. Renewed appreciation of rural coastal lifestyles saw growing popularity of second homes in coastal regions and the arrival of more affluent retirees (Connell and McManus 2011; Burnley and Murphy 2004), as well as countercultural movements of 'hippies', artists and musicians who sought idyllic retreat from urban ills (Gibson 2002). Benefits of such in-migration have been unevenly experienced throughout the region. Merimbula has 
become a popular second-home coastal town, with accompanying retail, hospitality and cultural industries growth. Bega (an inland dairy town) has struggled, economically and demographically. A first wave of in-migration arrived during the 1970s when a small population seeking alternative lifestyles moved to the Bega Valley. Newly arrived migrants brought an infusion of visual arts, writing, music and other forms of creativity. Their chosen areas of settlement were Tanja (population 381), Candelo (population 339) and Wyndham (population 610) all of which today still boast artistic presences, despite their diminutive status.

The research from which this paper draws was conducted over a year, with one author living in the Bega Valley in 2012 as part of a higher degree research thesis (Gordon 2012). Research involved qualitative methodologies of observation, semi-structured interviews and 'vox-pop' interviews (short conversations conducted at music performances, festivals or choir rehearsals). Recruitment occurred via advertisements and 'snowballing'. Semi-structured interviews gave participants opportunities to share individual experiences and stories. Carefully worded vox-pop questions ('How long have you lived in the Bega Valley? What do you like best about participating in music?') allowed participants in community music programs to describe personal experiences, with minimal burden or imposition on their time. A narrative approach to analysis, using an iterative process of manual coding of recorded interview transcripts, focussed on meanings and relationships described by participants. In all, 28 people were interviewed. A majority was over the age of 40, female, and of AngloAustralian decent (with the exception of one Aboriginal participant) (Table 1).

$<$ Table 1 about here>

\section{Challenges to making music in a small country town}

Remoteness presents challenges of accessibility when it comes to enjoying and creating live (and recorded) music (Luckman et al 2008). Long distances between towns and scant public transportation result in an over-reliance on private motor vehicles, which not everyone can afford. A small and seasonally fluctuating population places pressures on commercial music venue managers to balance between offering gigs to local musicians versus bringing in new acts for the region's listeners. For these reasons, the region's music practices are not dominated by concerts or 
regular weekly live performances in pubs, clubs or theatres - what one would find in a typical urban 'scene' or commercial music space (cf. Cohen 1999). The small local population places limits on the availability of weekly live music. Many local bands finance their own self-produced recordings and sell CDs at gigs, aspiring to commercial success, but there is no significant intellectual property generation of the sort associated with major recording companies. Unlike larger metropolitan music scenes, there is no defining 'Bega Valley Sound' (cf. Connell and Gibson 2003).

During the tourist season (summer months), cafés and clubs host more frequent live shows to cater to visitors. Such opportunities are, however, limited to the coastal holiday towns, and are often taken up by touring musicians from elsewhere that venue managers believe will attract the holiday crowds. These are typically 'cover bands' who perform facsimile versions of familiar pop and rock songs that holidaymakers will recognise, and that add to the summer 'party' atmosphere. There are practically no other live paid performance opportunities. This was a constant source of frustration for local musicians. Kyle, a young Bega musician, described the situation in town:

the lack of gigs and the lack of a music scene, as well as a general lack of interest from punters [customers] in the area, especially young people, often makes me frustrated, and looking for opportunities elsewhere. (Interview, 2012)

For young musicians to gain practice opportunities, and improve their performance and exposure, playing shows is considered necessary. Ideally, musicians hone their act via a circuit of live music venues. Yet Jeff, a manager of one Bega venue explained the difficulty with booking local acts too frequently:

We've tried a lot of local [musical content] but what I've found with the local performers is that initially, the first time they play, generally, they draw a lot of people but... I try not to book them more than twice in three months. I try and stretch it out a bit and each time they're getting less and less [audience members]. They couldn't really sustain an interest on a regular basis. So we're trying now to get people in, more high profile performers. (Interview, 2012)

Jeff highlighted one of the dilemmas of playing music in a small town: overexposure is inevitable. Even the most loyal of family and friends will falter in their enthusiasm 
to return to watch the same performance week-in, week-out. Those artists who rely on the same few venues for performance opportunities eventually saturate the market. Meanwhile venue managers - especially in pubs, which are the dominant local commercial live music spaces in Australia (Homan and Johnson 2003) - are ultimately interested in consistently high audience numbers in order to maximise alcohol sales. Unlike in Ireland, for instance, where pubs have traditionally housed lively, informal acoustic community music sessions (Morton 2005), in Australian pubs the spaces designated for music are separate, formal 'back rooms' - what were once 'ladies' bars' or 'lounge rooms' that have been converted into mini concert venues, featuring electrified rock bands and DJs, with built-in public address systems. These are only available for hire on a commercial basis, with pub venue managers expecting a profit to be made over the bar or through door takings. Small populations in country towns fuel a perennial desire among pub venue managers to bring in outside talent from the cities to encourage better attendance - and greater alcohol consumption - at shows. This in turn limits opportunities for local musicians, who are forced to look to larger capital cities or possibly out-migrate altogether (cf. Bennett 2010) for regular paid performance opportunities through the pub circuit.

Accessibility is another major factor mitigating audience attendance at paid gigs. For young people, age restrictions, limitations on liquor licences and a need for car transportation limit their ability to attend shows. Young drivers must adhere to a zero blood alcohol limit, which acts against attracting youthful audiences at pub music venues. Venues may also have associated stigmas of undesirable fellow patrons musicians struggling to attract crowds to pubs or clubs that have bad reputations as 'rough', 'drinking barns' or 'pick-up joints' (Waitt and de Jong 2011). But for the majority of residents the key issue affecting attendance at local shows is mobility. According to Kyle,

It is very hard to get a following in this area, due to the lack of interest in live music, and people's unwillingness to travel from town to town to see music. People from Bega are unlikely to travel to Eden to see a gig. (Interview, 2012)

Although some commute between towns for education and work, when it comes to entertainment residents generally stay within their own towns. Tyler explained, 'it's 20 kilometres to Merimbula and 18 kilometres to Bega. If people want to come out 
for the night and have a few drinks they're not gonna - they can't drive' (Interview, 2012). Although such circumstances may not be unique to rural areas they are nevertheless amplified in sparsely populated settings.

The outcome of these various factors is that a coherent music industry associated with commercial venues, paid performances, and bands aspiring to recording careers in the wider music industry, never quite coalesces. That is not to say that music is rare, or an unimportant concern. Musicians who live in the Bega Valley must find alternative ways of making music and playing to audiences - and indeed, they have succeeded at this. To explain how such vibrancy emerged, against the odds, requires focus not on music as a burgeoning commercial creative industry (as the prevailing orthodoxy in regional development circles might suggest), but on the resourceful creation of a lively community music scene, outside the commercial sphere. The Bega Valley's geographic and socio-economic limitations have triggered those with an insatiable desire to make and perform music to create their own opportunities through grassroots creativity (cf. Mayes 2010b; Waitt and Gibson 2013). From a willingness and desire to share and involve residents in musical activities a core of individuals have carved out the real heart of the Bega Valley's musical identity: community music.

\section{Making community music}

Community-run music in the Bega Valley has a very different look and feel to the commercial circuit of pub gigs, and aspiring recording artists. Community music is supported by art societies, and a core group of directors and music fans who together plough enormous amounts of time, gratis, into organising and performing events. Festivals organised by non-profit societies and committees offer musicians important performance opportunities, and places to listen to and meet national and international artists. As explained below, grassroots productions and groups are not impermeable to issues of mobility and critical mass, and they struggle with funding. Nevertheless, the music fans of the Bega Valley continue to find alternative, non-profit and/or noncommercial spaces (cf. Waitt and Gibson 2013), and carve out new ways of playing and listening to music. 
Unlike the seasonal commercial venue scene, which concentrates on a narrower range of styles that appeal to summer holidaymakers, community music activities across the Bega Valley embrace a mixing of styles, genres and skills: folk musicians, classicallytrained instrumentalists, blues musicians, and choirs. The community music scene's diversity reflects the degree of experimentation and creative freedom possible when not bound by the need to make money by performing as 'greatest hits' cover acts in pubs. It also demonstrates how, in sparsely populated areas, genre eclecticism results from the need to 'band together' to support musical initiatives beyond one's immediate personal preferences (cf. Luckman, et al 2008). As Nick explained: 'there's an element of engaging with everybody and putting out the feelers to get everybody you possibly can; and even those who can't play you just say 'no worries, come along!' (Interview, 2012). Whereas in more highly and densely populated locations it may be possible to sustain highly specialised music scenes around individual genres (punk, reggae, country etc), in sparsely-populated and remote rural areas genre diversification and a shared ethos of supporting music-making outside one's own taste circles are necessary creative adaptations.

Whereas there are limited opportunities for musicians to develop a following via the pub circuit, in the community music scene there are opportunities to enjoy live music throughout most of the year. Arts societies in the Bega Valley (Table 2) provide social outlets for the musically inclined and performance opportunities for local established and aspiring musicians. They range from award-winning youth production company, Momentum Music, to the popular and well-established Candelo Arts Society.

Activities range from monthly bush dances to special fundraising events (such as for famine relief, or bushfire or earthquake appeals). Most events tend to focus on local talent but for larger shows, and in the case of charity fundraisers, musicians from outside the Bega Valley also perform. As non-profit organisations, all groups except South East Arts require annual (low-cost) memberships, for which members receive reduced ticket prices and regular club updates.

The Candelo Arts Society is one of the longest running groups, having operated for twenty-six years. Larry, Candelo resident and spokesperson for the Society, explained: 
We have acoustic circles and sometimes we just do half local people and then we have a feature act where someone comes and performs for us. Coming up we have a 'Bird Night' which is bird calling or bird poems... it's very varied [laughs]. Then every second year we've had festivals...the first Saturday of the month we have a bush dance at Kameruka [Hall] and then the third Friday of the month we have an M\&V (music and variety) night. (Interview, 2012)

Important to community music enterprises is skill in securing cheap (or free) rehearsal and performance spaces. Community music enterprises generally do not use pubs where the emphasis is on cover bands and profit from alcohol sales - and instead book town halls, community halls, bowling clubs and local cafes for their events. Rents are often token, rather than at commercial rates. Many such residual state and community facilities have survived from another era of cultural provision (cf. Martin and Pierce 2013). Meanwhile informal spaces are often sought - hence choirs frequently rehearse in members' lounge rooms, and classical music ensembles rehearse in the more spacious of their members' backyards (Figure 2). Creative frugality abounds.

$<$ Figure 2 about here>

A cohort of musicians and directors organise and run community music programs in the Bega Valley. Nick described: 'You find that it's the same bunch of teachers that are doing it all. There's five or six of us just sort of handling all the groups' (Interview, 2012). Directors often have more than one group for which they are responsible. Geoffrey Badger, a professionally trained musician who moved to the Bega Valley over 20 years ago, is in charge of two choirs and the Bega Valley Chamber Orchestra. He described what the Bega Valley was like when he moved there:

There wasn't much going on actually back then. If I wanted to be involved in say, I really love sacred choral music, and if I wanted to participate in that then I had to actually generate it. I had to make it happen. (Interview, 2012)

Absence of viable commercial opportunities spawned alternatives, with the rural setting and its challenges spawning a do-it-yourself mentality of enduring, that in turn 
enhanced ongoing participation. Badger reflected that: 'the interesting thing is that I have done more music here than most of my counterparts in the city and probably had more fun doing it' (Interview, 2012).

Community music in the Bega Valley includes larger productions, contemporary choirs (including mixed as well as specialist youth, men's and women's choirs), and concerts associated with the highly successful contemporary music event, the Four Winds Festival. Large instrumental ensembles include the Bega Brass Band, Bega Valley Chamber Orchestra and the Sapphire Coast Concert Band. Smaller instrumental groups are both formal and informal. Larger amateur theatre productions find roles for local musicians singing, writing music and playing instruments. Jane, a Candelo musician, described informal groups:

[a local musician] has started a beginners group in the school for any adult who wants to learn an instrument And so it's a band, and the only provisory is that you don't play something you are already good at. Lots of musicians join to learn a new instrument. It is a huge role model to the children. (Interview, 2012)

For Valley residents who lack the confidence to join formal orchestras, ensembles or choirs, at-home groups were convenient alternatives because they increased confidence levels and skills in a supportive environment. Suzanne, a local director of an at-home choir, described their philosophy:

It's not a huge choir. It's probably ten people but on any fortnight I would probably get seven or eight come... And it's just sort of turned out. It's more a choir for people who maybe haven't had a chance before... With one or two exceptions they've never done anything like that before. For them it's a really nice experience just to have a go.

Types of learning varied from physical singing skills to reading music and helping increase singers' confidence. Community music in this instance is not about pathways to commercial success, but about giving people a chance to learn an instrument, or gain confidence to sing, for their own sake. Community music invites social participation, often by those people who might in commercial concerts otherwise stay put firmly in the audience. 
Whether a performance is sold out matters less to musicians who create community music for sheer visceral pleasure (though such pleasures are invariably heightened with larger and appreciative crowds). When economic returns are not the principle concern driving an event, people enjoy playing music irrespective of commercial pressures. Candelo musician Heath Cullen said of the Candelo Art Society's open mic nights: 'it's a very supportive atmosphere, everyone is encouraging and joins in' (in Shedden 2012). The essence of the Bega Valley's community programs is not captured in their repertoire, or membership numbers, but in their approach, in the process rather than bottom line outcome, in the simple enjoyment of quality music.

Absence of a commercial opportunities can paradoxically broaden musicians' horizons, necessitating skill in creative frugality as a key element of cultural resourcefulness: the capacity to marshal resources, call on favours, and put on shows with minimal funding. As is the case in commercial music scenes, community music involves key gatekeepers who mediate performance opportunities (Gallan 2012). Prestige and commercial appeal are not, however, prominent factors mediating access to opportunities. As Nick, a choir director and educator, explained:

The interesting thing is in Sydney or Canberra or Melbourne people are really interested in your CV and who you've worked with. Whereas here they just really want to know what kind of person you are and once they realise you're a good person then you get all the support you can imagine. (Interview, 2012)

In the Bega Valley, where the focus tends to fall on being organised and socially connected, personal dispositions and traits are paramount.

\section{Adjusting to change: community music and in-migration}

Community music programs, events and clubs have proven a means for in-migrants to adjust to a new environment and develop social networks. Michael, who moved to the Bega Valley in 2010, said:

There's usually something on... it's very diverse and really active for a small little community. See, I came out of Adelaide, a big city, a million people, and 
there's plenty of music there, so I wondered when I came here what it would be like - and I was very pleasantly surprised in the breadth and the depth of it. (Interview, 2012)

The Candelo Arts Society offers a variety of events that are a good way for new residents to meet others. Larry described moving to Candelo with his wife and how the Arts Society introduced them to other music fans from town:

The community is so good here and if you have a slight interest in music you go along and they're very willing to accept you... we didn't know anybody when we came here. And joining groups, especially the Arts Society, we've met heaps of people. (Interview, 2012)

Parents are also able to make connections through music schools. Doug, a new resident to the Bega Valley, described how the school his children attended allowed him to connect with parents with similar musical interests: 'I've met many people through the school. Between there and posters I've found a group of people to play [music] with' (Interview, 2012).

Participants spoke fondly of the resulting support systems, knowledge sharing and a sense of comfort and trust among fellow musicians and singers. Gabrielle, a participant in an all-women choir, described the social support that resonated within the group:

Someone might come in and they just had some bad news - their mum's sick or dying, or their child's not well... everyone knows and they're there for them, and they say: 'well we're glad you're here'. They're grabbing them and putting their arms around them. That person just starts crying and everyone holds the person who's crying. Or someone's pregnant and everyone's laughing and they're saying 'come on you!', or someone's got a new boyfriend and they're like 'Ohh you!!' and all the sex jokes come out. It's just really, because it's women, the bond... and the power of the group keeps people coming every week.

All-women's choirs in the Bega Valley provide a much-needed place for women to tell stories and share worries, to share knowledge, skills and to ask questions on topics ranging from child-bearing to home renovations. Gabrielle explained her own feelings towards this type of companionship: 
so you're having a baby, and you're at the point where the baby is this age and you don't know what to feed it or it's having a problem and it's not eating... you go [to choir] and you've got this pool of knowledge. There's twenty women who've brought up kids... Or if you've found out you have cancer or you want to know where you can get your mother into a home. You've got twenty women all different, you know? One's run a business... another's worked in China... and one's travelled the world... and another - I dunno, worked in a brothel! Who knows? They just know so much between them... it mimics that whole thing about the circle of people, and the tight knit group of a community, like we used to have in the old villages and stuff like that. I used to feel like they were my elders... All these women gathering together with all of their knowledge and wisdom.

Social networks are important to all communities, but in rural areas where smaller and dispersed populations tend to provide fewer spaces for face-to-face social interaction, community music groups are important spaces for knowledge sharing, and emotional support.

In a rural region the in-migration of even one or two key musicians can have a notable impact on the music community. Incoming musicians can re-write a small town's musical identity quite quickly, and improve availability of certain cultural and arts programs. The vibrancy of the Bega Valley's musical communities was in turn a cultural attractor that encouraged further in-migration (cf. Verdich 2010). Lola, a newly arrived resident, explained:

We moved away from the hustle of a busy town in Melbourne, and we have chosen to live here in Bega for its beautiful surroundings, beautiful people, and great music! (Interview, 2012)

For Jessica, who has been in the Bega Valley for ten years,

I have certainly seen more professional musicians moving to the area, which is fantastic... I think for a lot of people the reason why they want to live somewhere like Candelo is because of the vibrancy of the musical community. We have a ridiculous number of people [laughing] who are musically inclined. (Interview, 2012) 
Moving to the Bega Valley has encouraged in-migrating musicians to create or participate in different styles of music than in larger cities. But remoteness from big city gatekeepers also liberated rural musicians to experiment and explore diverse influences without recourse to metropolitan trends (cf. Gibson et al 2010). Jeff explained: 'you haven't got as many opportunities in a way, but you've got different types of opportunities as well. You have the freedom to do things here that you probably can't do in Melbourne or Sydney or Canberra' (Interview, 2012).

\section{Limitations and challenges}

Although community music has generated cultural vibrancy and encouraged resourcefulness, limitations and challenges persist. Funding, accessibility, geography and a small population challenge community music programs, choirs and ensembles to remain viable in participation terms. Mobility remains a huge constraint. A Bega choir director, Nick, explained,

The biggest problem is the distance... this time of year I am thinking okay, I am going to do orchestra this day, Monday afternoon, and choir's going to be on Thursday afternoon. The bus comes in from Pambula at 4:15pm so I have to have my rehearsal at $4: 20 \mathrm{pm}$. It's all related to when you might be able to get people here, because you can't rely on parents to just drive and there's no public transport. So just getting people together is really quite a difficult thing. (Interview, 2012)

Driving at night in the Bega Valley is hazardous, on twisting unlit roads, with a high risk of hitting wildlife. People of all age groups, but especially those who are older, rarely venture out after dark: 'there's music going on at the Hotel in Tathra, and the Cafe in Bega but I don't drive at night. Well I might go if there's a special event but there's just too many 'roos [kangaroos]' (Doug, interview, 2012). Mary, a member of a Bermagui choir, described how she waited patiently for a local choir to be established, so she would not have to drive across the Bega Valley for rehearsals: 'I just love to sing and I was waiting for a local choir because I didn't want to travel. I waited 12 years to get one nearby' (Interview, 2012).

With long distances between towns, community music participants find themselves spending a great deal of time in their vehicles. Suzanne, a Bega Valley choir director, 
educator and band member, described the travel necessary to teach her classes and groups, and participate in her own band:

I have a rehearsal tonight [in Bega] and yesterday I went to Bermagui for the rehearsal; that's about 40 minutes there and back. And tonight I am going to Wolumla. That's 15 minutes down the highway. Then I got to drive back here [Bega] and then to Brogo which is another 20 mins. All those things take up your time and your money. (Interview, 2012)

Community music participants nevertheless exercise resourcefulness and creative frugality, looking to share petrol and the drive. Jesse, a Cobargo resident and member of a choir in Bega, said: 'I tend to just work until five to seven [rehearsal starts at $8 \mathrm{pm}]$ and then come here, so it makes it quite a long day. But I live in Cobargo and so a few of us live there and we carpool' (Interview, 2012). Despite the need to rush to choir after work, residents like Jesse felt that it was worth the effort: 'Monday night's work music is not very convenient but I have just made it a priority now because I wanted to have singing in my life' (Interview, 2012). The region's Children's Choir meanwhile has overcome such limitations by being comprised of three smaller groups which rehearse separately, with different directors, in the towns of Candelo, Bega and Bermagui. The three groups combine for performances three-to-four times annually.

A lack of funding combined with the costs of licensing to legally perform other people's work, present financial challenges for non-profit cultural groups (cf. Baker 2007; Waitt and Gibson 2013). Geoffrey described negotiating the cost of sheet music, and the importance of creative frugality, dealing directly with composers, and emphasising his choir's social purpose and non-profit status:

Music's expensive and if we want to perform anything in the last hundred years then we're looking at much more money than we can generate with the socio-economic pool that we're in... I find myself ringing contemporary Australian composers and just saying: 'Geoffrey Badger from Bega, and we'd like to do your [work]'. And they say, 'yeah sure, no worries, feel free!' There's a lot of goodwill amongst the Australian music community. (Interview, 2012) 
Despite long distances, lack of critical mass, and financial constraints, aspirations to musical excellence endure. Nick explained his own perseverance to achieve high standards in music education programs:

I take the artistry seriously too. I want them to perform well and my vision is a very high standard. I am not saying 'oh yeah, whatever they can manage is okay'. I am always pushing them for very high standards.

The focus on quality, confidence building, and enjoyment of music making has inspired a healthy population of aspiring musicians and singers. Despite and because of their very demographic and economic constraints, rural places in Australia can thus catalyse rewarding, albeit particular, creative opportunities. Ultimately, community music enriches rural cultural life and fosters a sense of belonging in place:

it might not be working for the Sydney Symphony or another big musical organization but... it's still at [a high quality] level... I think that most people fall into the trap that they think they have to actually perform a lot with major touring groups or whatever, and they're always looking for the next step to take them up the ladder. Whereas you know, I am here with my family and just want to stay here and enjoy this really nice life. It's very much the feeling that I am making this life as good as it can be for me, as much as for the people around me. (Nick, Interview, 2012)

Settling into a life of rural creativity is no mere concession to 'second-best' amateurism. Geographic and imagined marginality is not a correlate for poor quality. Choirs in the Bega Valley do not hold auditions, yet they have performed with the Canberra Symphony. Local orchestras cannot afford to buy sheet music, yet at festivals, and on tour, perform alongside the best classically trained Australian musicians. Geoffrey described:

We've done a lot of collaborative stuff, like live music and contemporary dance... We've had quite famous Australian contemporary dance choreographers and educators come and just go 'wow, this is the best original dance company in the country!' And it's just happening down in the basketball stadium in Bega. (Interview, 2012) 
At the time of writing, and following recent uploading of performances to YouTube, one of the Bega Valley's longest-running choirs, Heartsong, had received an invitation by Distinguished Concerts International New York (DCINY) to participate in a performance of Ola Gjeilo's Sunrise Mass at Carnegie Hall in New York City (Virtue 2015). Rural creativity can flourish even in - and perhaps also because of challenging circumstances. Even when commercial opportunities are scarce, and problems of distance and smallness intervene, people find ways to enrich their lives with music.

\section{Conclusions}

At a time when the ongoing vitality and resilience of rural and remote settlements are at the forefront of policy discussions (Hogan and Young 2012; Connell and DuftyJones 2014), it is worth appreciating the role played by cultural initiatives outside the commercial sphere. Creative industries may indeed struggle to contribute to rural prosperity through formal employment generation (Argent et al 2013), but smaller community run productions and programs contribute to rural cultural resourcefulness, encouraging creative frugality, engaging passionate people to express themselves, and to endure. In the Bega Valley, where a commercial music scene struggles to survive, residents have taken it upon themselves to generate programs, groups and festivals. Our study has thus sought to further contribute to breaking down preconceptions that rural towns are, because of their failure to support notable commercial creative industries, somehow intrinsically devoid of cultural activity (cf. Mayes 2010b). As Nick described:

There's a sense where a lot of people sort of see us [people in rural areas] as impoverished in a way of arts and culture... but certainly Bega is a bubble at the moment of really amazing music and art. There is a cultural sort of hum. (Interview, 2012)

Grassroots community music productions are a window into music's deeper meanings, and into collaborative efforts that are inspired not by money but by a desire to create and share music for cultural enrichment (cf. Hesmondhalgh 2013). Music making survives through key local agitators and advocates, and through efforts in creative frugality that pull together resources, people and goodwill (Smith 1997; 
Luckman et al 2008; Gallan 2012; Ward and O'Regan 2015). Community music programs also enrich the Bega Valley as an enjoyable and rewarding place to live (cf. Veblen 2008). There are additional qualities of encouraging active face-to-face participation - an antidote to isolation - and inclusivity (cf. Baker 2007). Community music programs and groups are principally vehicles to play music, to tap into the visceral pleasures that come from performing music for and with others; but they also bring people together in circumstances that can be socially, mentally and physically isolating. In parallel (but also distinctive) ways to sporting clubs (cf. Tonts 2005), such activities contribute to regional development holistically, by enriching cultural life, proliferating and deepening social relationships, and encouraging newcomers to settle and establish friendship networks.

Community music demonstrates the presence in rural areas of seldom-acknowledged cultural capacities to adapt to and cope with vulnerability and challenging circumstances (cf. Head et al 2011; Anderson 2014; McManus et al 2012). Conditions of isolation, risk of commercial failure and economic hardship are catalysts for bringing people together to experiment with different ways to sustain cultural participation, in turn inspiring personal and community growth (cf. Derrett 2009; Anwar McHenry 2011). The cultural sphere here is key: music is more than mere pastime, but a source of human flourishing, emotional sustenance, pleasure and release that people find ways to support, even if economically constrained (cf. Hesmsondhalgh 2013). Bega Valley residents, as with other rural Australians, struggle with isolation and loneliness, floods, droughts and reduced levels of accessibility to needed services. Nevertheless dedicated and generous people continue to organise, and participate in, the region's array of community music groups.

Community music demonstrates the enduring value of the arts and creativity for catalysing rural cultural resourcefulness - developing capacities to draw upon cultural norms and emotions, and to exercise creative frugality, in adapting to a challenging, sparsely populated physical environment. As our interviewee Nick put it: 'I can make things happen if I put my mind to it, so you know, anything I have wanted to do I have been able to do' (Interview, 2012). Within community music there are key gatekeepers - directors and coordinators who steward musical productions, non-profit committees and clubs with their own internal dynamics - but there is also an 'all 
hands on deck' mentality that sustains activities beyond the commercial sphere. This is a key cultural resource in rural life, not just in music, but also across a myriad of other activities, where shared norms of local resolve and sources of place attachment prevail. 


\section{References}

Anderson, D. (2008) Drought, endurance and 'the way things were': The lived experience of climate and climate change in the Mallee. Australian Humanities Review 45.

Anderson, D. (2014) Endurance: Australian Stories of Drought. Melbourne: CSIRO Publishing.

Anwar-McHenry, J. (2009) A place for the arts in rural revitalisation and the social wellbeing of Australian rural communities. Rural Society 19, 60-70.

Anwar-McHenry, J. (2011) Rural empowerment through the arts: the role of the arts in civic and social participation in the Mid West region of Western Australia. Journal of Rural Studies 27, 245-253.

Argent, N., Tonts, M., Jones, R. and Holmes, J. (2013) A creativity-led rural renaissance? Amenity-led migration, the creative turn and the uneven development of rural Australia. Applied Geography 44, 88-98.

Baker, S. (2007) Young people and community radio in the northern region of Adelaide, South Australia. Popular Music and Society 30, 575-590.

Beer, A., Tually, S., Kroehn, M. and Law, J. (2012) Australia's country towns 2050: What will a climate adapted settlement pattern look like? Gold Coast: NCCARF.

Begg, R. (2011) Culturing Commitment: Serious Leisure and the Folk Festival Experience. In Gibson, C. and Connell, J. (eds) Festival Places: Revitalising Rural Australia. Bristol: Channel View, 248-64.

Bell, D. and Jayne, M. (2010) The creative countryside? Policy and practice in the UK rural cultural economy. Journal of Rural Studies 26, 209-218.

Bennett, D. (2010) Creative migration: a Western Australian case study of creative artists. Australian Geographer 41, 117-128.

Bristow, G. and Healy, A. (2015) Crisis response, choice and resilience: insights from complexity thinking. Cambridge Journal of Regions, Economy and Society 8, 241256.

Breen, M. (1994) Constructing the popular from public funding of community music: notes from Australia. Popular Music 13, 313-326.

Burnley, I. and Murphy, P. (2004) Sea Change. Sydney: UNSW Press.

Cloke, P., Goodwin, M. and Milbourne, P. (1998) Cultural change and conflict in rural Wales: competing constructs of identity. Environment and Planning A 30, 463480. 
Cocklin, C. and Dibden, J. (2004) Sustainability and change in Rural Australia. Sydney: UNSW Press.

Cohen, S. (1999) Scenes. In Horner, B. and Swiss, T. (eds) Key terms in popular music and culture. Malden: Blackwell, 239-250.

Connell, J. and Dufty-Jones, R. (2014) Rural Change in Australia: Population, Economy, Environment. Farnham: Ashgate.

Connell, J. and Gibson, C. (2003) Sound Tracks: Popular Music, Identity and Place, London: Routledge.

Connell, J. and McManus, P. (2011) Rural Revival? Place Marketing, Tree Change and Regional Migration in Australia. Farnham: Ashgate.

Davies, A. (2014) Urban to rural elderly migration renewing and reinventing Australia's small rural towns. In Connell, J. and Dufty-Jones, R. (2014) Rural Change in Australia: Population, Economy, Environment. Ashgate: Farnham, 43-56.

DeNora, T. (2000) Music in Everyday Life. Cambridge University Press.

Derrett, R. (2009) How festivals nurture resilience in regional communities. In AliKnight, J., Robertson, M., Fyall, A. and Ladkin, A. (eds) International Perspectives of Festivals and Events. Oxford: Elsevier, 107-24.

Duffy, M. (2000) Lines of drift: festival participation and performing a sense of place. Popular Music 19, 51-64.

Edwards, R. (2012) Gympie's country music muster: creating a cultural economy from a local tradition. Journal of Rural Studies 28, 517-527.

Eriksen, C. (2013) Gender and wildfire: Landscapes of uncertainty. London: Routledge.

Finnegan, R. (1989) The Hidden Musicians Music-Making in an English Town. Middletown: Wesleyan University Press.

Gallan, B. (2012) Gatekeeping night spaces: the role of booking agents in creating 'local' live music venues and scenes. Australian Geographer 43, 35-50.

Gibson, C. (2002) Rural transformation and cultural industries: popular music on the New South Wales Far North Coast. Australian Geographical Studies 40, 336-356.

Gibson, C. and Connell, J. (2012) Music Festivals and Regional Development in Australia. Farnham: Ashgate.

Gibson, C. and Connell, J. (2015) The Role of Festivals and Events in DroughtAffected Australian Communities. Event Management 19, 445-460 
Gibson, C. and Klocker, N. (2005) The 'cultural turn' in Australian regional economic development discourse: neoliberalising creativity? Geographical Research 43, 93-102.

Gibson, C., Luckman, S. and Willoughby-Smith, J. (2010) Creativity without borders? Re-thinking remoteness and proximity. Australian Geographer 41, 25-38.

Gibson, K. (2001) Regional subjection and becoming. Environment and Planning D: Society and Space 19, 639-667.

Gordon, A. (2012) Community Music, Place and Belonging in the Bega Valley, NSW, Australia. MSc Thesis, University of Wollongong.

Head, L., Atchison, J., Gates, A. and Muir. P. (2011) A finegrained study of the experience of drought risk and climate change among Australian wheat farming households. Annals of the Association of American Geographers 101, 1089-1108.

Hesmondhalgh, D. (2013) Why Music Matters. Oxford: Wiley-Blackwell.

Hesmondhalgh, D. and Baker, S. (2013) Creative Labour: Media Work in Three Cultural Industries. London: Routledge.

Hogan, A. and Young, M. (eds) (2012) Rural and Regional Futures. London: Routledge.

Homan, S. and Johnson, B. (2003) Vanishing Acts: An Inquiry into the State of Live Popular Music in New South Wales. Sydney: Australia Council.

Hracs, B. (2012) A creative industry in transition: the rise of digitally driven independent music production. Growth and Change 43, 442-461.

Imperiale, A.J. and Vanclay, F. (2016) Local community resilience in action: learning from post-disaster communities. Journal of Rural Studies 47, 204-219.

Joseph, D. (2007) Sharing music and Culture through singing in Australia. International Journal of Community Music 2, 169-181.

Langston, T.W. and Barrett, M.S. (2008) Capitalizing on community music: A case study of the manifestation of social capital in a community choir. Research Studies in Music Education 30, 118-138.

Leyshon, A. (2014) Reformatted: Code, Networks, and the Transformation of the Music Industry. Oxford University Press.

Lockie, L. and Bourke, S. (eds) (2001) Rurality Bites; the social and environmental transformation of rural Australia. Pluto Press: Annandale.

Luckman, S. (2012) Locating Cultural Work: the Politics and Poetics of Rural, Regional and Remote Creativity. Palgrave: London. 
Luckman, S., Gibson, C., Willoughby-Smith, J. and Brennan-Horley, C. (2008) Life in a northern (Australian) town: Darwin's mercurial music scene. Continuum 22, 623 637.

MacKinnon, D. and Derickson, K.D. (2013) From resilience to resourcefulness: a critique of resilience policy and activism. Progress in Human Geography 37, 253270.

Martin, J. and Budge, T. (eds) (2011) The Sustainability of Australia's Country Towns: Renewal, Renaissance and Resilience. Ballarat: Victorian Universities Regional Research Network Press.

Martin, D. and Pierce, J. (2013) Reconceptualizing resistance: residuals of the state and democratic radical pluralism. Antipode 45, 61-79.

Martin, R. and Sunley, P. (2015) On the notion of regional economic resilience: conceptualization and explanation. Journal of Economic Geography 15, 1-42.

Mayes, R. (2010a) Doing cultural work: local postcard production and place identity in a rural shire. Journal of Rural Studies 26, 1-11.

Mayes, R. (2010b) Postcards from somewhere: 'marginal' cultural production, creativity and community. Australian Geographer 41, 11-23.

McManus, P., Walmsley, J., Argent, N., Baum, S., Bourke, L., Martin, J., Pritchard, B. and Sorensen, T. (2012) Rural community and rural resilience: what is important to farmers in keeping their country towns alive? Journal of Rural Studies 28, 20-29.

Miller, F., H. Osbahr, E. Boyd, F. Thomalla, S. Bharwani, G. Ziervogel, B. Walker, et al. (2010) Resilience and vulnerability: Complementary or conflicting concepts?

Ecology and Society 15, 11.

Morton, F. (2005) Performing ethnography: Irish traditional music sessions and new methodological spaces. Social \& Cultural Geography, 6, 661-676.

O'Brien, D. (2013) Cultural Policy: Management, Value and Modernity in the Creative Industries. London: Routledge.

Onyx, J. and Leonard, R. (2010) The conversion of social capital into community development: an intervention in Australia's outback. International Journal of Urban and Regional Research 34, 381-97.

Pritchard, B (1996) Shifts in food regimes, regulation, and producer cooperatives: insights from the Australian and US dairy industries, Environment and Planning A 28, 857-875.

Pritchard, B and McManus, P 2000, Land of Discontent the dynamics of change in rural and regional Australia. Sydney: UNSW Press. 
Pritchard, B., Argent, N., Baum, S., Bourke, L., Martin, J., McManus, P., Sorensen, A. and Walmsley, J. (2012) Local - if possible: how the spatial networking of economic relations amongst farm enterprises aids small town survival in rural Australia. Regional Studies 46, 539-557.

Rimmer, M. (2009) 'Instrumental' playing? Cultural policy and young people's community music participation. International Journal of Cultural Policy 15, 71-90.

Roberts, E. and Townsend, L. (2015) The contribution of the creative economy to the resilience of rural communities: exploring cultural and digital capital. Sociologia Ruralis 56, 197-219.

Scott, A.J. (2000) The Cultural economy of cities. London: Sage.

Scott, A.J. (2006) Creative cities: conceptual issues and policy questions. Journal of Urban Affairs 28, 1-17.

Shedden, I (2012) Musician hits high note in rural retreat. The Australian, 25 May. Accessed 2 June 2012, http://www.theaustralian.com.au/arts/music/musician-hitshigh-note-in-rural-retreat/story-fn9d2mxu-1226366093591.

Singh-Peterson, L. and Lawrence, G. (2014) Insights into community vulnerability and resilience following natural disasters: perspectives with food retailers in Northern NSW, Australia. Local Environment 1, 1-14.

Smith, S.J. (1997) Beyond geography's visible worlds: a cultural politics of music. Progress in Human Geography 21, 502-529.

Tonts, M. (2005) Competitive sport and social capital in rural Australia. Journal of Rural Studies 21, 137-149.

Tonts, M., Argent, N. and Plummer, P. (2012) Evolutionary perspectives on rural Australia. Geographical Research 50, 291-303.

Tonts, M., Plummer, P. and Argent, N. (2014) Path dependence, resilience and the evolution of new rural economies: perspectives from rural Western Australia. Journal of Rural Studies 36, 362-375.

van Vuuren, K. (2002) Beyond the studio: a case study of community radio and social capital. Media International Australia incorporating Culture and Policy 103, 94-108.

Veblen, K.K. (2008) The many ways of community music. International Journal of Community Music 1, 5-21.

Verdich, M. (2010) Creative migration? The attraction and retention of the 'creative class' in Launceston, Tasmania. Australian Geographer 41, 129-140.

Virtue, R. (2015) From online videos to New York City for Bega choir, Australian Broadcasting Corporation, 19 June, http://www.abc.net.au/local/stories/2015/06/12/4254042.htm 
Waitt, G. and de Jong, A. (2014) Embodied geographies of alcohol and the weekend in the Bega Valley, New South Wales, Australia. Leisure Studies 33, 116-132.

Waitt, G. and Gibson, C. (2013) The Spiral Gallery: nonmarket creativity and belonging in an Australian country town. Journal of Rural Studies 30, 75-85.

Walmsley, D.J. (2000) Community, place and cyberspace. Australian Geographer 31, 5-19.

Ward, S. and O'Regan, T. (2015) The Northern Rivers media sector: making do in a high-profile rural location. International Journal of Cultural Policy 21, 291-308.

Wheeler, S, Bjornlund, H, Zuo, A and Edwards, J (2012) Handing down the farm? The increasing uncertainty of irrigated farm succession in Australia. Journal of Rural Studies 28, 266-275. 
Table 1: Summary of participant information

\begin{tabular}{|c|c|c|c|}
\hline $\begin{array}{l}\text { Participant } \\
\text { (Pseudonym) }\end{array}$ & $\begin{array}{l}\text { Age, } \\
\text { Sex }\end{array}$ & $\begin{array}{l}\text { Music related role in the } \\
\text { Bega Valley }\end{array}$ & $\begin{array}{l}\text { Method of Participation in } \\
\text { Study \& Where }\end{array}$ \\
\hline Nick & 40s, M & $\begin{array}{l}\text { Musician, director \& } \\
\text { educator }\end{array}$ & Interview at home, plus email \\
\hline Gerry & $50 \mathrm{~s}, \mathrm{M}$ & Choir member & $\begin{array}{l}\text { Interview, community centre \& } \\
\text { email }\end{array}$ \\
\hline Stacy & $40 \mathrm{~s}, \mathrm{~F}$ & Director & Phone interview \\
\hline Kyle & $20 \mathrm{~s}, \mathrm{M}$ & Musician, educator & Interview at café, plus email \\
\hline Steve & $30 \mathrm{~s}, \mathrm{M}$ & Music director & Interview at Bega park \\
\hline Paul & $50 \mathrm{~s}, \mathrm{M}$ & Arts Society member & Interview at home \\
\hline Jan & $50 \mathrm{~s}, \mathrm{~F}$ & Works at local music school & Interview in music shop \\
\hline Shona & $20 \mathrm{~s}, \mathrm{~F}$ & $\begin{array}{l}\text { Musician, key player in local } \\
\text { festival }\end{array}$ & Interview at workplace \\
\hline Doug & $50 \mathrm{~s}, \mathrm{M}$ & Musician & Interview at café \\
\hline Lola & $30 \mathrm{~s}, \mathrm{~F}$ & Musician & Email exchanges \\
\hline Tyler & $50 \mathrm{~s}, \mathrm{M}$ & Venue owner & Interview at venue \\
\hline Jeff & $50 \mathrm{~s}, \mathrm{M}$ & Director, musician, educator & Interview at café, plus email \\
\hline Glen & $50 \mathrm{~s}, \mathrm{M}$ & Arts council member & Interview at office \\
\hline Sharon & $50 \mathrm{~s}, \mathrm{~F}$ & $\begin{array}{l}\text { Musician, educator, choir } \\
\text { member }\end{array}$ & Interview, community centre \\
\hline Jakob & $40 \mathrm{~s}, \mathrm{M}$ & Musician, director & Interview at home \\
\hline Michael & $50 \mathrm{~s}, \mathrm{M}$ & Festival volunteer/organiser & Interview at café \\
\hline Jean & $50 \mathrm{~s}, \mathrm{~F}$ & Choir member & Phone interview \\
\hline Gabrielle & $40 \mathrm{~s}, \mathrm{~F}$ & Musician, director & Interview at café \\
\hline Suzanne & $50 \mathrm{~s}, \mathrm{~F}$ & Musician, director & Interview at workplace \\
\hline Mary & $40 \mathrm{~s}, \mathrm{~F}$ & Choir member & Phone interview \\
\hline Beth & $73, \mathrm{~F}$ & Choir member & Vox pop, community centre \\
\hline Jacqueline & $61, F$ & Choir member & Vox pop, community centre \\
\hline Louis & $75, \mathrm{M}$ & Choir member & Vox pop, community centre \\
\hline Lisbeth & $60 \mathrm{~s}, \mathrm{~F}$ & Choir member & Vox pop, community centre \\
\hline Tim & $68, \mathrm{M}$ & Choir member & Vox pop, community centre \\
\hline Cathy & $57, \mathrm{~F}$ & Choir member & Vox pop, community centre \\
\hline Jesse & $40 \mathrm{~s}, \mathrm{~F}$ & Choir member & Vox pop, community centre \\
\hline
\end{tabular}


Table 2: Arts Societies, Bega Valley, NSW Australia, 2012

\begin{tabular}{|c|c|c|c|c|}
\hline Society & Location & $\begin{array}{l}\text { Number of } \\
\text { Members }\end{array}$ & Popular events/ Specialties & website \\
\hline $\begin{array}{l}\text { South East } \\
\text { Arts }\end{array}$ & $\begin{array}{l}\text { Based in } \\
\text { Bega }\end{array}$ & $\mathrm{n} / \mathrm{a}$ & $\begin{array}{l}\text { Support body for diverse arts programs and initiatives. Assist new } \\
\text { community music groups apply for grant money. }\end{array}$ & http://southeastarts.org.au/ \\
\hline $\begin{array}{l}\text { Candelo Arts } \\
\text { Society }\end{array}$ & Candelo & $150+$ & $\begin{array}{l}\text { Monthly: dances and music \& variety nights. } \\
\text { Annually: special concerts and performances from local and visiting } \\
\text { artists. } \\
\text { Organise Candelo Village Festival }\end{array}$ & $\begin{array}{l}\text { http://thebegavalley.org.au } \\
\text { /cas.html }\end{array}$ \\
\hline $\begin{array}{l}\text { Yuin Folk } \\
\text { Club }\end{array}$ & Cobargo & $200+$ & $\begin{array}{l}\text { Annually: special concerts and performances from local and visiting } \\
\text { artists. Organise Cobargo Folk Festival. }\end{array}$ & $\begin{array}{l}\text { http://www.cobargofolkfes } \\
\text { tival.com/page/comingeve } \\
\text { nts/ }\end{array}$ \\
\hline $\begin{array}{l}\text { Merimbula } \\
\text { Rock \& } \\
\text { Rodders }\end{array}$ & Merimbula & 30 & $\begin{array}{l}\text { Monthly dances. Organise Rock and Rodders 50s and 60s Dance } \\
\text { Festival. }\end{array}$ & $\begin{array}{l}\text { http://www.sapphirecoastr } \\
\text { ockandroll.com.au/Home. } \\
\text { html }\end{array}$ \\
\hline $\begin{array}{l}\text { Sapphire } \\
\text { Coast Music } \\
\text { Society }\end{array}$ & Merimbula & 114 & Organise musicals and concerts. & $\begin{array}{l}\text { http://thebegavalley.org.au } \\
\text { /scmusicsociety.html }\end{array}$ \\
\hline $\begin{array}{l}\text { Momentum } \\
\text { Music }\end{array}$ & Bega & $20+$ & $\begin{array}{l}\text { Host all-ages concerts. Also host productions through the year for } \\
\text { CAS and other organisations. }\end{array}$ & $\begin{array}{l}\text { http://www.facebook.com/ } \\
\text { pages/Momentum-Music- } \\
\text { Media/145618058799030 }\end{array}$ \\
\hline
\end{tabular}




\section{Figure captions:}

Figure 1: Location map, Bega Valley

Figure 2: Neighbours and friends gather for a Monday afternoon rehearsal of the Bega Brass Band in Tathra, NSW, 2012. A Tathra resident volunteered her lawn for an outdoor rehearsal, which drew in neighbours carrying drinks and snacks. 